\title{
Situating Nordic Girls' Studies
}

\author{
Bodil Formark and Annelie Bränström Öhman
}

\section{$\cos 80$}

While we have been working on this themed issue the political talk about The Girl has entered a new phase in a global shift manifested both by the establishment of the International Day of the Girl and through the launching of various campaigns on themes such as: Give Girls an Education and Eradicate World Poverty. The necessity for such initiatives was cruelly illustrated by the violent attack on Pakistani girls' rights activist Malala Yousafzai on her way home from school on 9 October 2012. Such blatant discrimination makes it difficult for us not to feel that we live in a privileged part of the world. The five Nordic nation states-Denmark, Finland, Iceland, Norway and Sweden - are indeed often perceived by outsiders, too, as progressive countries that have come very far in achieving gender equality. However, although Nordic girlhood may appear in stark contrast to that of the millions of disadvantaged girls in the world, there are complexities and ambivalences beneath the surface of Nordic progressiveness that a reductive, comparative, and linear, framework fails to take into account.

The societal model known as the Nordic model has, since the twentieth century, been a shared historical experience in the Nordic region. This entails, with some national variation, the organization of society characterized by a tax-funded and inclusive welfare system. However, as historians Henrik Berggren and Lars Trädgårdh (2012) have argued, it would be more accurate to understand Nordic societies as social investments states, rather than welfare states:

Though the path hasn't always been straight, one can discern over the course of the twentieth century an overarching ambition in the Nordic countries not to socialize the economy but to liberate the individual citizen from all forms of subordination and dependency within the family and in civil society: the poor from charity, the workers from their employers, wives from their husbands, children from parents_ and vice versa when the parents become elderly (14). 
The rationale for the extensive social engineering and the administration of welfare solutions via anonymous and institutionalized systems originates from an underlying moral logic that attributes an absolute value to both the autonomy of the individual and to social stability. The Nordic ambition to achieve gender equality on all levels in society can be regarded as a reflection of this underlying social contract (Berggren and Trädgårdh 2010; 2012).

The societal ambition to reform gender roles has indeed also created a set of very specific circumstances, challenges, and opportunities for generations of girls and women. Nordic girlhood rests on discourses that stress individual emancipation and gender integration of girls and boys. The gender integration of most parts of children's public life, such as child-care, coeducational schools and leisure-time activities (with the exception of sports) reflects a discursive emphasis on the innate likeness of girls and boys. Gender differences within this framework are understood, rather, to be a result of the socialization process. This produces a normative ideal that a girl can and should do whatever she wants and that girls are strong and independent. The gender likeness discourse thus downplays the structural dimensions of gender that might hinder the individual girl from choosing freely her being and becoming. Furthermore, concurrent with this conceptualization of how gender roles are created, there is an equally strong normative discourse that naturalizes girls as girly and that they therefore either cannot or should not play ice-hockey, for example, or behave as though they think they are just like boys. The particularity of the Nordic girlhood experience can thus perhaps best be understood as shaped by this co-existence and merging of likeness and difference (Frih and Söderberg 2010; Olsson 2011).

Parallel with the reforms for achieving gender equality from the $1960 \mathrm{~s}$ and onwards there has also been considerable structural continuity regarding the gendered value hierarchies, distribution of power, influence and economic resources and investments (Börjesson 1998). Beginning in the late 1980s the fact that girls were still disadvantaged and experiencing a number of gender-related challenges came under discussion, and a number of initiatives, such as girl group activities, were launched (Frih and Söderberg 2010). The investigation of the effects on girls' lives of this continual structural discrimination on a group level has also been a recurrent theme since the inception of Nordic Girlhood Studies. From the mid-1980s researchers from various academic backgrounds have investigated a wide array of young women's creative expressions and their circumstances within both youth culture and school environments. The label young women was a distinction based on age, but it also reflected an analytical preoccupation with genera- 
tional differences and the conflicting positioning of girls and girlhood within modern society (Drotner and Rudberg 1993; Bjerrum-Nielsen 2004). Because gender equality not only represents a political ambition, but also a cultural ideal in Nordic societies, young female subjects have had to negotiate a set of opportunities and pressures both as girls and as women in the making. For girls the intrinsic historical temporality of the notion of gender equality as something which was non-existent, but which is to be realized in the future, near or distant, has furthermore meant that the Nordic girl has been constructed as a main subject area for policy attention and political intervention (Formark 2013).

The effects of the targeting of girls as key-players in the realization of gender equality have recently been discussed through a metaphorical use of Astrid Lindgren's literary heroine, Pippi Longstocking. Finnish researchers Elina Oinas and Anna Collander argue that pippifeminism can be tracked as an emancipatory strategy that places the responsibility on the individual girl to make sure that she becomes, effortlessly, a gender equal woman (Oinas and Collander 2007; see also Österlund 2012). The ambivalent situation for Nordic girls thus stems from a political and social imperative that girls can and should be whatever or whoever they want to be, and that they can transcend the remaining injustices while simultaneously living and experiencing these injustices. How well girls succeed can thus become manifested as a measure of Nordic progressiveness and the gender-equal girl a legitimizing embodiment of this sought-after equality.

However, since the beginning of the 1990s the Nordic model has undergone considerable change that can be understood as an effect of the economic crisis of this particular decade, as a response to increased globalization, and as a result of intensified co-operation within the European Union. This reformation has, for example, meant a privatization of former monopolies along neo-liberal lines of freedom of choice. This has created, in addition, new work-practices in which there are signs that girls and young women are perceived to be the perfect embodiments of the ideal autonomous and ambitious neo-liberal subject (Sjöstedt Landén 2012). Such developments have happened concurrently with a backlash against feminism, and the growth and subsequent parliamentary successes of social-conservative, anti-globalization and xenophobic parties in most Nordic countries. Within the discourses of the radical right there is a defensive and nostalgic support of the Nordic model. Gender equality can, among such sentiments, be used as a racialized Nordic characteristic that is viewed as incompatible with multiculturalism. However, gender equality can also be perceived as something 
that has already been achieved: feminist voices for continued political reform can then be accused of wanting gender equality to go too far (Magnusson et al. 2008; Norocel 2012).

The renewed analytical interest in Girlhood Studies during the last couple of years must be understood in relation to the Nordic model, its reformation, and the current political and social polarization regarding gender, class and ethnicity. These have, since the twentieth century, created a set of culturally specific frictions for generations of girls in the Nordic countries. How then has the construction of young femininities and Nordic girls been affected by these circumstances?

In this issue such questions are explored and elaborated upon. We are proud to present articles that illustrate a range of different topics and perspectives within Nordic Girls' Studies. A shared departure point is, on the one hand, a critical perspective on gender equality as a political ideology, identity and discourse in the Nordic region, and, on the other, the differing effects of this discourse for girls and for the Nordic construction of girlhood. A common thread in several of the articles is an intersectional analysis of classic feminist imagery such as Virginia Woolf's intellectual-spatial metaphor of a room of one's own and its application. Woolf's metaphor is explicitly alluded to in the title of Cecilia Björck's article "A Music Room of One's Own: Discursive Constructions of Girls-only Spaces for Learning Popular Music." Björck analyzes how ideas about the necessity of a room of one's own become negotiated and intertwined with ideas that girls should ta plats [claim space] in discourses which permeate girls-only music initiatives in Sweden. Björck stresses the continuing importance of questions of empowerment when we are analyzing girls' participation in public life, but also draws attention to the benefits of non-transparent and more secluded girls-only spaces. The dynamic relationship between public and private arenas also unfolds in Ann Werner's article "Sexy Shapes: Girls Negotiating Gender through Popular Music." Werner investigates how a group of Swedish teenage girls with multi-ethnic backgrounds negotiate their gender identities in their discussions of their favorite music and female artists. Werner shows how the girls' individual and collective formations of femininity and sexuality are both articulated as a desire for music through a polarizing discourse on ethnic identity and national belonging as well as an adaption to heteronormativity.

The complex relation between and among gender equality, multiculturalism, ethnicity and agency is further investigated in Veronika Honkasalo's article "Save the Girls!" Gender Equality and Multiculturalism in Finnish Youth Work Contexts." Through interviews with youth workers, Honkasalo 
finds that gender equality is often used as a marker of Finnishness and she discusses the ways in which the identification of gender inequality is habitually associated with girls from migrant backgrounds. Honkasalo shows how the idea of youth work as gender-neutral and as an equality-based practice is often an illusion that reflects an ideal of equality rather than being concretized as a professional practice.

Karolina Dmitrow-Devold in "'Superficial! Body Obsessed! Commercial!' Norwegian Press Representations of Girl Bloggers.” demonstrates another aspect of the ambivalent status of gender equality in everyday life. Dmitrow-Devold takes as her point of departure the fact that teenage girls occupy the top positions in Norwegian blog rankings, but are often dismissed as superficial and trivial by the media. Dmitrow-Devold argues that the media phenomenon of pink blogging must be understood as part of deeply gendered media discourse. The article highlights striking examples of this bias in the mainstream press coverage in which pink bloggers are represented as popular but insignificant, trendsetting but irresponsible, savvy but vulnerable, and also as being exploitative of the commercial potential of their blogging.

The adolescent girl's sexualized body as an object of potential risk is analyzed by Lisa Lindén in "'What Do Eva and Anna Have to Do with Cervical Cancer?' Constructing Adolescent Girl Subjectivities in Swedish Gardasil Advertisements." Lindén investigates the direct-to-consumer advertising for the HPV-vaccine Gardasil in Sweden as a contemporary gendered technology. She finds that the visual and textual representations of different girl subjectivities in the advertisements are designed to fit the purpose of marketing the use and consumption of Gardasil as a responsible decision, and as part of growing up. In various ways, girls (along with their parents) are encouraged to assume responsibility for managing their risks of cervical cancer in order to help secure their future health, sexuality and normality.

In Anna-Karin Frih's article, "Becoming Healthy, Free and Physically Active: Medical Discourse on Girls in Sweden c. 1880-1930," the discursive battle over the girl and her body is set against an historical backdrop. Frih examines the medical discourse on girls, and their activity and health in Sweden during the transition from the nineteenth to the twentieth century. The study reveals patterns of the medicalization of girls as well as categorizations and constructions of girlhood that corresponded with contemporary but changing notions of gender.

Finally, in Myry Voipio's "Light, Love and Desire: The New Wave of Finnish Girls' Literature," the range of this issue is further extended to 
include the representation of girls' bodies, emotions and relationships in contemporary Finnish literature. Voipio analyses four contemporary novels and pays attention to how adolescent female sexuality is depicted in comparison to the dictates of the generic conventions of girls' literature. Voipio finds that even if the narratives of desire and love in these novels include lesbian and bisexual relationships, they still hold on to some of the genre characteristics of girls' literature. The challenge is, it seems, conditionally articulated and thus holds a similar ambivalence to the girl as emancipatory subject as the debate on gender equality as a whole does.

This fascinating selection of articles most surely contributes to the development of a critically oriented Nordic Girlhood Studies that is brave and reflexive enough to question whether gender equality is an actual situation that Nordic girls can live without effort and negotiation, and to scrutinize this claim. It is therefore our hope that this themed issue will contribute to a much needed nuancing of the image of the Nordic countries as a place where gender inequality has been resolved and the struggle for girls' rights is over.

Bodil Formark received her Ph.D. in history in 2011 for a dissertation about Girl Scouting in Sweden from 1910 to 1940. She has recently completed a postdoc at the Department of Historical, Philosophical and Religious Studies, Umeå University, working on a project about how the historiography of women's history has been used to promote feminist awareness in girls. Bodil is one of the founders and board members of FlickForsk! Nordic Network for Girlhood Studies.

Annelie Bränström Öhman is Professor of Literary Studies in the Department of Culture \& Media Studies, Umeå University, Sweden. In her research, as well as in her teaching, she has been oriented mainly towards three areas: feminist theory, creative writing, and love. She has written extensively about modernist erotic poetry and issues concerning love in Sara Lidman's novels. In the field of Girls' Studies she is primarily interested in themes like the elasticity of age in literary representations of girlhood and elderly womanhood. Annelie is also involved in FlickForsk! 


\section{Acknowledgments}

Serving as Guest Editors has been a privilege. We would like to express our gratitude to all the authors of the articles for their enthusiasm, promptness and patience. Thanks also to all the Nordic and international reviewers. We would like to offer special thanks to Managing Editor Ann Smith with whom it has been such a joy to work. Last, but not least, our deepest appreciation and gratitude go to Claudia Mitchell and Jacqueline Reid-Walsh for giving us this opportunity, for their expertise, and for their guidance from day one onwards.

\section{References}

Berggren, Henrik, and Lars Trädgårdh. 2010. "Pippi Longstocking: The Autonomous Child and the Moral Logic of the Swedish Welfare State." Pp. 50-65 in Swedish Modernism. Architecture, Consumption and the Welfare State, ed. H. Mattson and S.O. Wallenstein. London: Black Dog Publishing.

Berggren, Henrik, and Lars Trädgårdh. 2012. "Social Trust and Radical Individualism: The Paradox at the Heart of Nordic Capitalism.” Pp.12-29 in The Nordic Way. Equality, Individuality, and Social Trust. Stockholm: Svenska Institutet.

Bjerrum Nielsen, Harriet. 2004. "Noisy Girls: New Subjectivities and Old Gender Discourses." Young 12, no. 9: 9-30. doi: $10.1177 / 1103308804039633$

Börjesson, Agnes. 1998. Flickorna och frigörelsen: Forskning om flickor och arbete med tjejprojekt. Stockholm: Ungdomsstyrelsen.

Drotner, Kirsten, and Monica Rudberg, eds. 1993. Dobbeltblikk på det moderne: Unge kvinners hverdagsliv og kultur i Norden. Oslo: Universitetsforlaget.

Formark, Bodil. 2013. "Jösses flickor, vilket trassel! Historiska reflektioner kring flickforskningens uppgift i en flickfrämjande och postfeministisk tid.” Tidskrift för genusvetenskap, no. 2-3: 7-20.

Frih, Anna-Karin, and Eva Söderberg, eds. 2010. En bok om flickor och flickforskning. Lund: Studentlitteratur.

Magnusson, Eva, Malin Rönnblom and Harriet Silius, eds. 2008. Critical Studies of Gender Equalities. Nordic Dislocations, Dilemmas and Contradictions. Stockholm: Makadam Publishers.

Norocel, Ov Christian. 2012. “'Give Us Back Sweden!' A Feminist Reading of the (Re)Interpretation of the Folkhem Conceptual Metaphor in Swedish Radical Right Populist Discourse." Nora: Nordic Journal of Feminist and Gender Research 21, no. 1: 4-20. doi: 10.1080/08038740.2012.741622 
Oinas, Elina, and Anna Collander. 2007. "Tjejgrupper: rosa rum, pippifeminism, hälsofrämjande?” Pp. 275-299 in Kvinnor, kropp och hälsa, ed. E. Oinas and J. Ahlbeck-Rehn, Lund: Studentlitteratur.

Olsson, Jenny-Leontine. 2011. Kön i förändring: Den svenska könsrollsforskningen 1959-1979. Lund: Sekel Bokförlag.

Sjöstedt Landén, Angelika. 2012. "A Fantasy of the 'Ambitious Young Girl' as Flexible Knowledge-worker Subject." Nora: Nordic Journal of Feminist and Gender Research 20, no. 3: 249-265. doi: 10.1080/08038740.2012.747787

Österlund, Mia. 2012. "Nordic Girlhood Studies: Do We Need to Get over the Pippi Longstocking Complex?” Pp. 35-42 in Peripheral Feminisms: Literary and Sociological Approaches, ed. Petra Broomans and Margriet van der Waal. Groningen: Centre for Gender Studies, Euroculture, Globalisation Studies. 